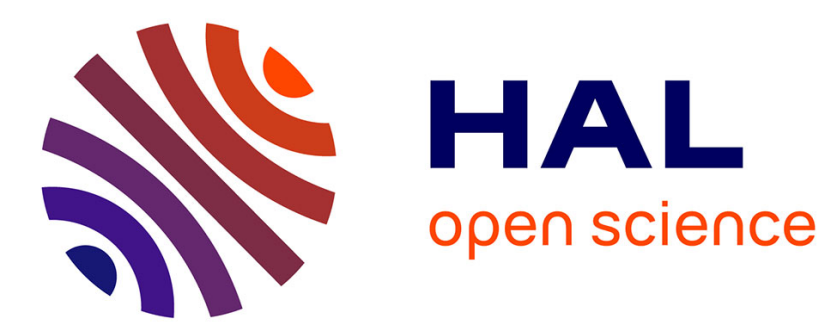

\title{
Building a narrative on environmental policy success: reflections from a watershed management experience \\ Sylvain Barone
}

\section{To cite this version:}

Sylvain Barone. Building a narrative on environmental policy success: reflections from a watershed management experience. Critical Policy Studies, 2018, 12 (2), pp.135-148. 10.1080/19460171.2016.1194765 . hal-01804968

\section{HAL Id: hal-01804968 \\ https://hal.science/hal-01804968}

Submitted on 1 Jun 2018

HAL is a multi-disciplinary open access archive for the deposit and dissemination of scientific research documents, whether they are published or not. The documents may come from teaching and research institutions in France or abroad, or from public or private research centers.
L'archive ouverte pluridisciplinaire HAL, est destinée au dépôt et à la diffusion de documents scientifiques de niveau recherche, publiés ou non, émanant des établissements d'enseignement et de recherche français ou étrangers, des laboratoires publics ou privés. 


\title{
Building a Narrative on Environmental Policy Success. Reflections From a Watershed Management Experience
}

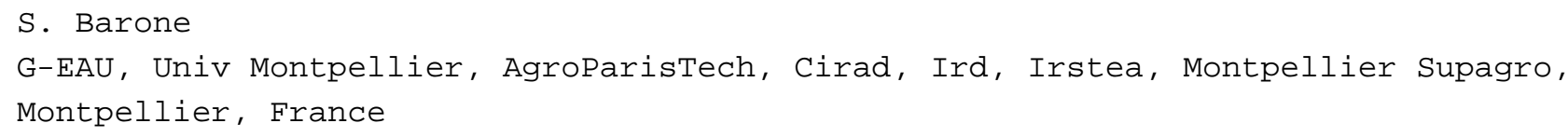

\begin{abstract}
:
This article deals with the advent of a narrative on environmental policy success. While a positivist position would begin by determining a certain number of supposedly objective criteria of success, we consider success as the result of a process aiming at stabilizing a particular interpretation of a situation. We study the case of a French lagoon presented by many actors as a success in terms of watershed and environmental management. We seek to analyze how this narrative on success was built and became dominant thanks to the intervention of particular actors and how, in return, these actors managed to reinforce their domination, both in the territory under study and in the water policy sector in France.
\end{abstract}

\section{Key-words:}

Success; narrative; environmental policy; watershed management; France 


\section{Introduction}

When is a policy successful? ${ }^{1}$ One first way of answering this question, also the most positivist, starts with determining a number of supposedly objective success criteria (efficiency, efficacy, effectiveness, to only name a few) and expecting in return an equally objective measure of success. Many public policy evaluations fall into this category. Nonetheless, sociological analysis of public policy has gradually distanced itself from it. Policy analysts began with emphasizing subjectivity, the relativity of success and failure, as well as the complexity involved in establishing them (Kerr, 1976; Ingram and Mann, 1980). Some are still reflecting on an acceptable framework by which to define what makes a public policy successful (Bovens, á Hart, and Peters, 2001; Boyne, 2003; McConnell, 2010; Marsh and McConnell, 2010). Other authors understand policy success to be a ñmobilizing metaphorò (Shore and Wright, 1997).

Still others rather convincingly consider success as the result of a process aimed at stabilizing a particular interpretation of a situation and at promoting a given model of public action (Rap, 2006; Mosse, 2004). For these authors, the ability to mobilize ever increasing and powerful actors is crucial in order to impose their interpretation of the situation in the face of other possible interpretations. Above all, the fact that a public policy is called successful will therefore reveal the success, in a specific institutional context, of a narrative initiative led by actors gathering a number of resources (Hajer, 1995; Radaelli, 1999; Schmidt and Radaelli, 2004). One might say that the stabilization of a particular interpretation is one possible measure of success $\ddot{i}$ that can be contested or just perceived as a temporary fix. Of course, we did not intend to impose our own objective indicator, but rather to explore the interpretative dimension of policy success by analyzing how actors are striving to structure and impose, if possible durably, their interpretations of the situation.

More precisely, we examined the construction of a narrative on environmental policy success in the context of our research on watershed management. For the last ten years, one of our study sites, the Thau lagoon in the South of France, has been unanimously recognized as embodying a kind of success story in the field of environmental policy. The success of Thauôs environmental policy has become a leitmotiv and a nearly foregone conclusion. This article focuses on understanding how this narrative on success has been built by specific configurations of actors and how it has managed to become predominant in a few years.

\section{A Policy Narrative Approach}

Policy narratives have been defined as "stories (scenarios and arguments) which underwrite and stabilize the assumptions for policymaking in situations that persist with many unknowns, a high degree of interdependence, and little, if any, agreement" (Roe, 1994, 34). They often

\footnotetext{
${ }^{1}$ Gabrielle Bouleau and Christelle Gramaglia contributed to the first version of this text. Their reflections are still structuring this article. I would like to thank the three anonymous reviewers for their constructive comments and insightful suggestions as well as François Molle for his interesting observations and proofreading.
} 
take the guise of causal stories (Stone, 1989). Narratives organize the world by creating order within disorder (Hajer and Laws, 2006). Resulting from the selection of specific elements of reality, they "have important political properties in terms of what they leave out - unspoken facts" (Radaelli, 2000, 272). Narratives condense a vast quantity of factual information and connect them to normative conceptions which lend them meaning. As such, the meaning of a public policy owes as much to the actorsôpreexisting beliefs as to their interpretation of given events.

Narratives are all the more effective if they lend themselves to multiple interpretations (Hajer, 1995). This echoes a paradox which has long been known by sociologists, that of the "power of haziness" (Boltanski, 1982). The intrinsic vagueness of a narrative enables it to unite beliefs and interests which were in principle incompatible. In public policy, this haziness sometimes gives way to unexpected compromises or ambiguous agreements (Palier, 2005), which gather together varied or even contradictory interests (Hajer, 2011). Coalitions are made up both of a "common public statement" and of "a group of subjective, discrete statements which resonate as infinite interpretations and variations of this common statement for each of the actors who have made it theirs" (Zittoun, 2013, 206). Though many actors share one particular narrative, it does not prevent them from having, on certain points, differing concerns and agendas, which explain these interpretations and variations.

At the same time, narratives need to gain support in order to counter other possible causal stories. In this perspective, what we hold as truths are first stories which have been progressively presented as plausible by "influential interpreters" (Fischer, 2003, 43). That is what authors like Rap (2006) or Mosse (2004) show regarding policy success. In this competition for the discursive hegemony, actors seek out support to their own definition of reality (Edelman, 1964). As such, a narrative analysis only takes meaning if the narrative dimension of public policy is connected to the actorsôstrategies and to power asymmetries (Radaelli, 2000; Schmidt, Radaelli, 2004; Feindt and Oels, 2005). Once it has become dominant, a narrative gives power to certain actors. It redirects collective preferences. Ideas which stray from the dominant narrative are perceived as irrelevant or strange. At last, when a narrative is associated with powerful actors, it is likely to have performative effects (Foucault, 1969; Van Assche et al., 2012; Beunen et al., 2013). Policy success, in particular, can become a self-fulfilling prophecy (Mackenzie, Muniesa, 2007).

In this paper, we analyze the advent of a narrative on environmental policy success: how do actors give meaning to public policy by promoting particular interpretations of a situation? What kinds of actors are involved and what kinds of mobilizations are observed? In short, how to explain the success of this narrative on policy success? Answering these questions will lead us to address the links between this narrative and the distribution of power and domination in the institutional fields under study.

At this stage, a heuristic distinction must be introduced between two main institutional fields: the water policy sector and the local territory. Policy sectors reflect a division of governmental work based on the production of an expertise that is considered to be legitimate (Benson, 1982; Jobert and Muller, 1987; Sabatier and Jenkins-Smith, 1993). Hence, water management refers to a sector with its own expertise, specialized institutional actors and dominant concepts. At the same time, public policy is implemented in a differentiated way depending on the territory. In France, this distinctive feature has been reinforced by laws on decentralization, which have been ongoing since the beginning of the 1980s (Douillet and Faure, 2005; Faure and Négrier, 2007). Water has not been an exception to this evolution. 
Although water management has always been ensured by local authorities (Barraqué, 1995), their responsibilities in this regard have increased considerably over the last two decades. Watershed management policies are therefore implemented both by sectoral and territorial actors, and it is reasonable to think that Thau's success narrative was not shaped in the same way by these two types of actors.

\section{Methodology}

Our inquiry is based on a field investigation carried out between 2010 and 2014 as part of two research projects ${ }^{2} .39$ face-to-face semi-structured interviews were conducted with actors involved in the governance of Thau territory (see table 1). We then proceeded to a qualitative analysis of interview data.

[Table 1]

Furthermore, observations were made through regular participation in local assemblies and meetings about watershed management and land planning issues. In particular, we attended many assemblies of the Local Water Commission, which is the local water ñParliamentò setting general objectives at the scale of the catchment. We also attended public meetings during the process of elaboration of the water management plan and of the territorial land use planning, as well as some municipal and intercommunal associationsô councils. These interviews and observations were supplemented by examining grey literature: official reports, water management and land planning documents (like the local Sea Development Plan, the Water Management and Development Plan or the Territorial Coherence Plan), financial partnership (like the ñLagoon Contractsò), local authoritiesôbudgets and periodicals, etc. We also followed the local press (particularly Midi Libre, a regional newspaper). Through these methods, we were both looking for factual information in order to describe Thaû́ experience, and for interpretations in order to analyze the narrative dimension of public policy.

Following the aforementioned analytical distinction between the sectoral and the territorial institutional fields, we will start by describing the role of water policy makers in promoting the Thau experience. We will then analyze how this narrative building resonates with dominant interpretations at the local level.

\section{Promoting an Exemplary Experience}

The construction of Thau's success narrative first results from the intervention of sectoral actors looking for local policies that could be showcased and promoted as exemplary experiences of watershed management. Yet this evolution was far from being straightforward.

\subsection{The Origins of the Narrative on Success}

Thau is a 7,500 hectare coastal lagoon about thirty kilometers West of Montpellier, in the South of France. Its biodiversity is considered to be extremely rich, both in terms of its fauna

\footnotetext{
${ }^{2}$ I-FIVE (Innovative Instruments and Institutions In Implementing the Water Framework Directive) European project, Integrated Water Resources Management (IWRM)-Net, 2009-2011; SURGE (Solidarité Urbain-Rural et Gestion de lốEau) project, Water and Territory program (Ministry of the Environment, CNRS, Cemagref), 20112013.
} 
and its flora (Verlaque, 2001). The area's main economic activities are the port of Sète, sea and lagoon fishing, shellfish farming, inland viticulture, and tourism, mainly along the coastline. The lagoon also harbors several industrial facilities and thermal activity. The vulnerability of shellfish farming and lagoon fishing, which depend on the health of lagoon water and provide several thousand jobs, is put forward as a justification for many local decisions. Lagoon fishing and shellfish farming are major features of local life (Giovannoni, 1995; Sécolier, 2009). Concurrently, and much like most of Languedoc, Thau developed viticulture in the $19^{\text {th }}$ century. But the phylloxera crisis caused a drop in wine production. Chemical factories first appeared in the 1890s, mainly to meet the needs of viticulture. The region also began hosting oil refineries. In the 1950s and 1960s, the southern part of the Thau basin was the only industrial complex in the region (Verlaque, 1987). The 1970s economic crisis had widespread consequences, as the most important factories were closed. In the 1960s, a policy of large-scale tourism development was launched with the construction of about twenty port infrastructures and seaside resorts. The Interministerial Mission for the Development of the Coastal Zone, also known as the Racine Mission (1963-1983), was tasked with developing tourism in Languedoc, with the threefold objective of capturing tourism flows heading for Spain, diversifying tourism destinations on the French Mediterranean coast, and bringing solutions to the wine crisis which was affecting Languedoc. Yet this massive project did not fundamentally change Thau's landscape or economy.

Thau's specificity in terms of watershed management was established at the end of the 1980s, when the 1986 "coastal law," aiming at limiting coastline urbanization, started to be implemented. This implementation would prove tricky along the Languedoc coastline, which had been strongly influenced by the Racine Mission. At that time, the mayor of Montpellier, the regional capital located about thirty kilometers from Thau, did not hide his will to transform the Thau lagoon into a place devoted to tourism while integrating it into Montpellier's area of influence. In 1989, State territorial services introduced the Schéma de Mise en Valeur de la Mer (Sea Development Plan), the first of its kind in France. The aim of the plan was to regulate all the uses of the lagoon, including shellfish farming, fishing, urbanization, tourism, agriculture, industry, etc. Several months after its launch, pollution caused by sanitation network dysfunctioning led to a ban on selling shellfish. Few professionals were able to overcome this crisis.

However the Schéma de Mise en Valeur de la Mer, adopted in 1995, reasserted the priority of shellfish farming and fishing activities: "Thau's general calling as a place for fishing and maritime culture is the top priority. All the other activities must organize their development according to the specific constraints of fishing and maritime culture". Furthermore, between 1990 and 2009, 145 million Euros were invested in three successive "Lagoon Contracts" to improve water quality, which is indispensable to these activities. Activities were thus enlisted by State services, which were looking for allies to implement the 1986 "coastal law" in the face of powerful actors: employer organizations who wished to transform the lagoon into a vast industrial zone, actors in mass tourism operators, or property developers with connections with community representatives (Dedieu, 2006).

\subsection{An Exemplary Experience of Watershed Management?}

The 1989 crisis therefore triggered a fundamental turnaround in local public action. Since then, State services, and particularly the regional directorate for the environment, and the 
Rhone-Mediterranean and Corsica Water Agency ${ }^{3}$ have been regularly praising Thau as being the "perfect student" in terms of water management. They praise how the resource is managed here. It is, in their view, in keeping with the principles of "integrated water resource management" (IWRM), the dominant paradigm at the international level which underlie the 2000 European Water Framework Directive and dominates water management at all scales (Molle, 2009; Trottier and Slack, 2004) ${ }^{4}$ : (1) Management at the hydrographic basin level, and not at the scale of an administrative territory. Water management is overseen by a public organization (Syndicat Mixte du Bassin de Thau) whose perimeter covers the catchment ${ }^{5}$, understood as the relevant spatial management unit in the field of water; (2) Combined use of policy tools, including conventional regulations pertaining to declarations, authorizations and inspections, planning with the establishment of the Schéma dôAménagement et de Gestion des Eaux (SAGE, Water Management and Development Plan) ${ }^{6}$, and contractualization, including the implementation of various ñLagoon contractsò since the 1990s; (3) Jointly addressing "water" and "land planning" issues: not only is planning in these two policy fields carried out by the same organization at the same scale, which is perceived as positive, but orientations defined in the Schéma de Cohérence Territoriale (SCoT, Territorial Coherence Plan) ${ }^{7}$ are recognized here as being compatible with the priority of protecting water; (4) Stakeholdersô involvement: beyond the Local Water Commission, in which fishing and shellfish culture representatives are particularly active, the general public was consulted on various occasions (presentations, discussion meetings or exhibitions); (5) High level of involvement of research actors, thanks to the proximity of the scientific communities of Sète and Montpellier, a city which gathers many water researchers, all disciplinary fields included. A long history of collaboration between research institutions and local organizations ${ }^{8}$ exists in the region.

It is easy to understand why this territory has been the object of such promotion from State administrations: ñWe follow some [approaches] more closely when they warrant a methodological need, or, as is the case for Thau, because we want to benefit from innovations, so others may benefit from them as well. [é ] When I started working in this region in 2003, I remember my colleagues saying: 'all the prefects are talking about Thau"'. The Water Agency's view barely differs: "Thau is a water management laboratory [é ]. What

\footnotetext{
${ }^{3}$ Water agencies are public organizations which were established under the 1964 law, to govern six major watersheds. They collect royalties paid by water users, which are redistributed in the form of financial support to local authorities or private stakeholders. The Rhone-Mediterranean basin mainly covers five regions (ProvenceAlpes-Côte dôAzur, Languedoc-Roussillon, Rhône-Alpes, Franche-Comté and part of Burgundy).

${ }^{4}$ This concept is partly sustained by the catchment area approach that was established in France in the wake of the 1964 law. The "French model" was widely promoted by the government following the 1992 Rio Earth Summit, which amongst other things encouraged the creation of the International Network of Basin Organizations, in which the International Office for Water (held mainly by elected officials and representatives of leading French water companies and engineers) acts as permanent technical secretariat.

${ }^{5}$ A catchment area represents the area bounded by a crest line, on which running water finds itself in the same watercourse.

${ }^{6}$ Implemented by the 1992 law on water, the SAGEs were developed by the Commissions Locales de lốEau (CLE, Local Water Commissions), half of whom are elected officials from local authorities, a quarter are users, and the remaining quarter are State representatives. They set general objectives for water usage, improvement, quantitative and qualitative protection on the scale of a catchment area.

${ }^{7}$ Devised by joined municipalities, SCoTs set general space organization guidelines.

${ }^{8}$ For example, Ifremer (French Research Institute for Exploitation of the Sea) oversees a major mission of monitoring seashell production zones, Irstea (French National Research Institute of Science and Technology for Environment and Agriculture) conducts research in modeling, prospective studies and social sciences in partnership with the Syndicat Mixte du Bassin de Thau, the University of Montpellier carries out hydrology and life sciences research in partnership with shellfish culture professionals, etc.

${ }^{9}$ Interview with a director of the State's regional department in charge of the environment (September 2011).
} 
Author-produced version of the article published in Critical Policy Studies, 2016, N¹0(3), p.1-14

The original publication is available at

http://www.tandfonline.com/doi/full/10.1080/19460171.2016.1194765

Doi: 10.1080/19460171.2016.1194765

we really like here is decompartmentalization"10. "[The Agency welcomes] the level of maturity of this environmental process, bolstered by its excellent socio-economic approach [é ]. [Thau acts as a] pilot in the Rhone-Mediterranean and national basins"11.

\subsection{Good Environmental Status or Conformity with Dominant Standards?}

The current dominant role of the IWRM ("Integrated Water Resource Management") concept leads to put forward a succession of success-stories. National water policy makers are key actors in this process, either because they are convinced that the approach is virtuous, because few counter-scripts challenge them (Hajer, 2011), or because they could be professionally marginalized if they were too critical (Molle, 2008). Thau has therefore been fully promoted by the Water Agency and State administrations, which would like other sites to emulate its experience.

This is doubly interesting for them. On one hand, it allows them, via a concrete case, to continue promoting the so-called French model of water management at an international level. The decentralized day of the $6^{\text {th }}$ World Water Forum which took place, not coincidentally, in Sète in March 2012, is highly indicative of this interest. Local officials and technicians and national actors in water management intensely promoted policies implemented in this territory to an international audience. Its echo was not insignificant, as demonstrates this statement from the same day, by the head of the Coastal Area Management Program (created in 1980 to help implement the Mediterranean Action Plan): "examples such as Thau are rare in the Mediterranean, and we need examples of best practices. This is very important for all Mediterranean countries." On the other hand, as Stone reminds us, "complex causal explanations are not very useful in politics, precisely because they do not offer a single locus of control, a plausible candidate to take responsibility for a problem, or a point of leverage to fix a problem" (Stone, 1989, 289). Consequently, "the intellectual difficulties of translating the complexities of institutional analysis into concrete suggestions for development policy and practice are sufficiently daunting to make retreat to simpler models a constant temptation" (Evans, 2004 quoted in Molle, 2008, 146). Precisely, what the Thau case highlights is a condensed causal story which represents a promise of success for others (Mollinga and Bolding, 2004).

As elsewhere, success here is broadly "defined in terms [é ] of the prescriptions of the model itself" (Mosse, 1999: 328) and is therefore ensured from the moment the IWRM's formal rules are followed. Conforming to principles seems to take precedence over water quality (Rap, 2006). Success thus becomes partly self-fulfilling; or, to put it differently, the narrative on success becomes performative: giving a success label increases the chances of receiving attention from potential financiers, while financing creates positive conditions, further feeding into the success narrative. Thau does benefit from a very benevolent attitude from the RhoneMediterranean and Corsica Water Agency. In 2012, it promised to finance Thau's integrated management contract (2013-2017), to the amount of 15.1 million Euros out of the 50 million directly relating to the lagoon, much more than the European Union (7.9 million) and the urban community of Thau's Southern basin (7.1 million). This is a substantial amount given the size of the territory. Furthermore, in the mid-2000s, Thau's reputation allowed it to

\footnotetext{
${ }^{10}$ Speech given by the Director of the Rhone-Mediterranean and Corsica Water Agency at the 6th World Water Summit (March 15, 2012).

11 "Lôgence de lâeau salue les efforts de la lagune de Thau", Midi Libre, February 19, 2010.
} 
become an experimentation site for Integrated Coastal Zone Management ${ }^{12}$, again demonstrating the performative nature of the narrative on success.

\section{Environmental Policy Success as a Territorial Narrative}

We have seen how water policy actors had established a routine reference to Thau's success by using the words and arguments of the IWRM paradigm. However the coalitions which disseminate Thau's success narrative are not limited to the sectoral dimension of water management. They also deploy themselves on a territorial basis then including, among others, local elected officials.

\subsection{All Green? Local Elected Officials and Watershed Management}

Starting in the 1980s and especially the 1990s, as a result of decentralization laws, local authorities began assuming a much more important role regarding water and environmental issues. In Thau, ecologist Yves Pietrasanta was already one of the most important local representatives ${ }^{13}$. He started out by dedicating himself to pollution issues in the lagoon, especially during the 1989 shellfish culture crisis. He also objected to a costly sanitation system proposed by State services. Instead, he proposed what was thought to be a more ecological solution ${ }^{14}$. An "eco-site" and a scientific park were created around the new sanitation system, offering visits and educational activities. Many water specialists and managers rushed to the Northern shore of the Thau basin to see what was being hailed as an innovation (Barraqué, 2007) ${ }^{15}$, further strengthening the success narrative. When a Local Water Commission was established in 2007, Y. Pietrasanta became its president without any opposition. His way of telling Thauês story is filled with references to science and innovation: "The story of the Thau basin is closely linked to water and to the many innovations it has always triggered. Our technical and scientific know-how must be enhanced and developed". ${ }^{16}$ This is not surprising coming from a former university professor of chemistry who built part of his political eligibility on his scientific legitimacy. The century of elective mandates which he has accumulated all along his political career also allows him to base his domination on the territory as a traditional notable would, but also from the outside, by boasting what he can get for the Thau territory thanks to his other mandates ${ }^{17}$.

In 2005, in exchange for the financing of a third lagoon contract, State services imposed a catchment structure, the Syndicat Mixte du Bassin de Thau (SMBT, Thau Basin joint

\footnotetext{
${ }^{12}$ It is an internationally-promoted tool, as well as by the European Union, for promoting management which takes into consideration terrestrial, maritime, natural, economic and social aspects in a coastal area defined as a coherent territory. A national call for tenders was launched in 2005, which resulted in the selection of Syndicat Mixte du Bassin de Thau.

${ }^{13}$ Mayor of Mèze from 1977 to 2001, this former university professor of chemistry was Vice-President of the Departmental Council between 1972 and 2001, Vice-President of the Regional Council between 1992 and 1998 and between 2004 and now. He was also a member of the European Parliament from 1999 to 2004. In 1991, he became a founding member of Génération Écologie, a green party he has been presiding since 2011. Furthermore, he has been president of the Community of Communes of the North of Thau Basin since its creation in 2001.

${ }^{14}$ Lagooning, which eliminates effluents essentially through the sun and the wind.

${ }^{15}$ The national daily paper Le Monde even wrote an entire article devoted to the eco-site of Mèze. "An Hérault community proves that ecology is able to create jobs," Le Monde, March 19-20 1995

${ }^{16}$ SMBT infos, May 2010

17 "May I remind you that I am responsible for [environmental issues] in the Regional Council" (CLE, 02/11/2013); "The Regional Council supports you" (CLE 02/27/2014).
} 
association between the Community of Communes of the North of Thau Basin and Thau Agglo, the Agglomeration Community of the South). François Commeinhes, right-wing Mayor of Sète, President of the southern community of the basin and senator, has been presiding over the joint association since its creation. Unlike Y. Pietrasanta, this doctor and private hospital director did not base his political enterprise on environmental issues. However, as President of the SMBT, he was also in favor of structuring the local public action around protecting the lagoon environment: "Aquatic environments support local economy"; "Transforming Thau into the maritime garden of Hérault while our department is undergoing considerable expansion"; "Establishing a garden-territory as well as a production site" ${ }^{18}$. The same could be said of Pierre Bouldoire, former social worker, socialist mayor of Frontignan, departmental councilor, main opponent of F. Commeinhes in the local political landscape: "[The Thau basin is] a genuine ecological asset [é ] but also a genuine economic capital"; "The goal is to find not a static, but a dynamic balance between the environment and the economy". ${ }^{19}$ Whether they are specialists or not, local elected officials all refer more or less explicitly to IWRM principles, even if they reshape the dominant narrative slightly differently: "We can only rise to this challenge if we are able to implement a joint approach to water and land planning"; "considerations must be brought to the scale of the entire catchment"; "the key word is dialog. Integrated water management on the basin needs all partners to collaborate" ${ }^{\prime 20}$; "This major ambition, which has been driving us for years, comes under the scope of what is now called integrated management" 21.

The construction of this narrative must of course be considered in parallel with more strategic considerations (Schmidt, Radaelli, 2004; Feindt and Oels, 2005). Thau's environmental success story allows representatives to present a relatively original idea of collective interest within a territory where inhabitants are believed to be attached, for various reasons (environmental interest, identity ties, property valuation), to their outstanding environment, and where preserving this exceptional environment is considered to be an asset for economic development: shellfishing, but also camping, hotels, restaurants, water sports, etc. Furthermore, performing success as they do gives them hope to gain legitimacy by being associated with positive outcomes (as deemed by themselves, but also by others, as we have seen) of public policy (Scharpf, 1999).

\subsection{Shellfishing and the Definition of Local General Interest}

If State services, the Water Agency and local representatives are at the heart of the coalition at play in Thau, the role of various interest groups, such as shellfish farmers and fishermen, is more ambiguous. These activities represent 5,000 direct and indirect jobs locally and sales of over 30 million euros per year. They are systematically associated with the management of the watershed. Their participation in the management bodies is justified by the fact that their activity strongly depends on the quality of resources and by their status as custodians of this environment. Nonetheless, these heterogeneous and divided professional groups have a limited capacity for action. As a result, local water policy has less to do with the strategies and capacities of their representatives than with their enrollment in the environmental success narrative, by both State services and local authorities. As one of their leaders reckoned: "With

\footnotetext{
${ }^{18}$ SMBT Trade Union Council, September 212010.

${ }^{19}$ Midi Libre multi-editorial supplement, 2012. As mayors of Sète or Frontignan, the political need to flatter the concerns of the interaction group (Goffman, 1959) has obviously led representatives to significantly change their tune at times.

${ }^{20}$ Y. Pietrasanta, SMBT infos, May 2010

${ }^{21}$ P. Bouldoire, Midi Libre multi-editorial supplement, 2012
} 
view to the limited extent of the profession, compared for example to agriculture, we are heard more than we are represented. And we are systematically associated. 20 years ago, this wasn't the case. Each municipality wanted its own marina and private housing estate". ${ }^{22}$

In the dominant narrative, shellfish farming and fishing clearly have the lead role. Since the end of the 1980s, maintaining traditional activities and preserving the lagoon are seen as inseparable. This central connection in building a narrative rests on producing rationales whose power stems from the capacity to present "facts" (Majone, 1989): oysters are not only extensively farmed but they also consume organic matter and therefore play a "role as natural filters" $^{23}$; fishing and shellfish culture play a "major role in protecting and managing ecosystems, aquatic environments, landscapes and resources in a context of growing pressure in the land market"24. At first glance, it would be hard to hope for a more "sustainable" development or more "integrated" management of the water resource.

Major local representatives play a central role in the institutionalization of the narrative. This role does not match that of the policy broker (Sabatier and Jenkins-Smith, 1993), who publicizes conflicts and proposes compromises which elected officials are often associated with $\ddot{i}$ including when it comes to water (Munro, 1993). Their role is rather to convert the narrative on environmental policy success into an organizing principle of local public interest. Obviously, protecting the lagoon is one theme amongst many which will draw the attention of representatives (sports equipment, road networks, public transportation, schools, etc.) But it is mobilized to give meaning to local public action: "Territories have the desire to be pioneers and exemplary in terms of water resource management [é ] Economic activities which are closely connected with the territory's fundamental resources remain a central issue ${ }^{\prime 25}$. It is significant that in the budget of the conurbation authority of Sète, preserving natural resources comes first in terms of investment expenditures, with 9 million out of a total investment of 39 million in 2014.

However, the processes through which elements of the reality are selected and arranged in the success narrative occur at the cost of silences or unspoken facts (Radaelli, 2000). Thau is presented as an example to be followed regardless of the fact that, according to all the respondents, there are still many difficulties at a local level: "In Thau, there were three contracts, and combined expenditures of perhaps 150 million euros, yet microbiological issues persist. Thau remains the symbol of everything municipalities have implemented to meet their objectives. In spite of this, we're clearly not done yet" ${ }^{\prime 26}$. Amongst the culprits are agricultural effluents ${ }^{27}$ or "wild" urbanization and illegal construction, faulty or non-existent sanitation systems ${ }^{28}$. Furthermore, presenting fishing professions as serving the environment is at best an over-simplification: shellfish tables impede water circulation in the lagoon, farming areas release waste, and not every professional is equipped with settling tanks, even

\footnotetext{
${ }^{22}$ Interview with a manager from the Section Régionale de la Conchyliculture de Méditerranée (SRCM, Regional Division of Shellfish Culture in the Mediterranean) (September 2012).

${ }^{23}$ Interview with an SMBT project manager (October 2009)

${ }^{24}$ SMBT, Choix dồne stratégie pour le SAGE, February 2011, p. 45

${ }^{25}$ SMBT, Un projet pour le territoire de Thau. Contribution au PADD du SCoT, 2009, p. 6.

${ }^{26}$ Interview with Languedoc-Roussillon Regional Council project manager (November 2009).

27 "Nitrates, nitrogen... There are also phytosanitary products and phytopharmaceuticals, herbicides, parasite treatments, etc. Products which are widely used by the farming profession in the catchment area." Interview with an SMBT manager (October 2009).

28 "Every municipality has doubled in size. At this rate, I'm no longer worried about tourists. The development plan of municipalities has been implemented haphazardly. Thau counts a thousand illicit constructions". Interview with a departmental elected official (June 2011).
} 
though they are mandatory. These aspects are rarely brought up, especially in Local Water Commissions, where this type of technical discussions would usually occur. These unspoken facts make the narrative possible. They shape an "ambiguous agreement" (Palier, 2005) which, because of its polysemy, gathers together a great variety of concerns and interests.

\section{Conclusions}

Let us go back to our introductory question: how was built the narrative on Thauôs environmental policy success? As we have seen, answering this question equates to asking how some views come to prevail over others. The success narrative results from the stabilization of a situation's given interpretation. The process is guided by actors whose power derives from their capacity to impose a narrative both within the water sector and the Thau territory. Thau's success narrative imposes itself as the dominant narrative at the scale of the territory thanks to its polysemy, which ensures that it can translate a plurality of expectations and interests. It rests on a declared conformity with dominant sectoral standards and mobilizes the IWRM vocabulary, which is flexible enough to be remobilized locally, taking on relatively varied meanings. This encourages water policy actors to turn the territory into an exemplary experience and thus make it benefit from special attention, illustrating the performative character of policy success. Building a narrative is made possible by formalizing an agreement around several supposedly proven facts. This agreement implies the existence of unspoken facts without which the causal sequence would be impossible.

We distanced ourselves from the notion that narratives would overestimate resilience and overvalue the capacity of actors to manipulate them. Firstly, the narrative which was examined here is embedded in wider structures of meaning and institutional frameworks, which encourage its expression. As it happens, narratives about watershed management are developed in a context of national and international domination of the IWRM paradigm, which inspires a significant number of norms in this field. Secondly, dominant narratives become institutionalized and subsequently need less effort to be sustained. As we have seen, this institutionalization can take various forms, such as organizational arrangements, budget priorities or territorial boundaries. In the end, we studied a multi-layered narrative whose strength came, precisely, from the ability to converge with broader dominant interpretations and interests in each institutional field. As far as local policies are concerned, at least, the heuristic distinction between sectors and territories may be useful to analyze the role of actors with different concerns and legitimacies and exposed to different paradigms and policy priorities in the construction/propagation of a narrative.

This analysis of an environmental policy put emphasis on at least two aspects which, far from being absent from other public action areas, gain particular prominence here. On the one hand, the highly spatialized dimension of this policy field (which also holds true for transportation or urbanism) makes the naturalization of management scales a constant temptation. Territorial division is one way of institutionalizing narratives, along with other classical channels (budgets, organizations, etc.). In our case, management at the level of the catchment is one of the factors which made the promotion of Thau as a success possible. This characteristic requires that special attention be given to the relationships between the territorial and the narrative ordering of the situation. On the other hand, beyond their evocative power, condensed stories seem to be the object of a specific use in the field of environment, by actors who find it difficult to spread their idea of a good policy differently, for example through numbered indicators. Socio-environmental contexts are indeed extremely 
diverse and environmental variables are not easy to standardize via measurements and enumeration (Asdal, 2008; Kohler, 2002). It could therefore seem more effective to promote one particular experience in order to indicate, with minimal cost, which is the "right" course of action.

\section{References:}

Asdal, K. 2008. "Enacting Things through Numbers: Taking nature into account/ing." Geoforum 39 (1): 123-132.

Austin, J. L. 1962. How to Do Things With Words. Oxford: Oxford University Press.

Barone, S., G. Bouleau, and C. Gramaglia. 2010. "Bridges between Lagoons: The Political Construction and Uses of a ósuccess Storyô in Thau and Berre (South France)." Paper presented at the 5th International Conference on Interpretative Policy Analysis, Grenoble, June 23-25.

Barraqué, B., ed. 1995. Les politiques de lâeau en Europe. Paris: La Découverte.

Barraqué, B. 2007. "Le lagunage: une rétro-innovation." Revue du Comité dốhistoire du ministère de lôEnvironnement 3: 61-69.

Benson, J. K. 1982. "A Framework for Policy Analysis." In Interorganizational Coordination: Theory, Research and Implementation, edited by D. L Rogers and D.A. Whetten, 137-176. Ames: Iowa State University Press.

Beunen, R. et al. 2013. ñPerforming failure in conservation policy: The implementation of European Union directives in the Netherlands.òLand Use Policy 31: 280-288.

Boltanski, L. 1982. Les cadres. La formation dôın groupe social. Paris: Editions de Minuit.

Bovens, M., P. ó T Hart, and B. G. Peters. 2001. "Analysing Governance Success and Failure in Six European States." In Success and Failure in Public Governance: A Comparative Analysis, edited by M. Bovens, P. ó H Hart, and B. G. Peters, 12-33. Cheltenham: Edward Elgar.

Boyne, G. A. 2003. "What is Public Sector Improvement?" Public Administration 81 (2): 211227.

Dedieu, O. 2006. "Lôhuître et le technocrate. Lôménagement intégré du littoral face aux professions halieutiques." In Pêche et Aquaculture. Pour une exploitation durable des ressources vivantes de la mer et du littoral, edited by J. Chaussade and J. Guillaume, 487495. Rennes: Presses Universitaires de Rennes.

Douillet, A.-C. and A. Faure, eds. 2005. Lâation publique et la question territoriale. Grenoble: Presses universitaires de Grenoble.

Edelman, M. 1964. The Symbolic Uses of Politics. Urbana: University of Illinois Press.

Evans, P. 2004. "Development as Institutional Change: The Pitfalls of Monocropping and the Potentials of Deliberation." Studies in Comparative International Development 38 (4): 30-52.

Faure, A., and E. Négrier, eds. 2007. Les politiques publiques à lấpreuve de lấction locale: critiques de la territorialisation. Paris: LôHarmattan.

Fischer, F. 2003. Reframing Public Policy. Discursive Politics and Deliberative Practices. Oxford : Oxford University Press.

Foucault, M. 1969. L'Archéologie du savoir. Paris : Gallimard. 
Author-produced version of the article published in Critical Policy Studies, 2016, N¹0(3), p.1-14

The original publication is available at

http://www.tandfonline.com/doi/full/10.1080/19460171.2016.1194765

Doi: $10.1080 / 19460171.2016 .1194765$

Giovannoni, V. 1995. Les pêcheurs de lấtang de Thau. Ecologie humaine et ethnologie des techniques. Paris: LơHarmattan.

Goffman, E. 1959. The Presentation of Self in Everyday Life. Harmondsworth: Penguin.

Hajer, M. A. 1995. The Politics of Environmental Discourse. Ecological Modernization and the Policy Process. Oxford: Oxford University Press.

Hajer, M. A. 2011. Authoritative Governance. Policy-Making in the Age of Mediatization. Oxford: Oxford University Press.

Hajer, M. A., and D. Laws. 2006. "Policy Frame and Discourse." In The Oxford Handbook of Public Policy, edited by M. Moran, M. Rein, and R. E. Goodin, 407-424. Oxford: Oxford University Press.

Ingral H. M., and D. E. Mann, eds. 1980. Why Policies Succeed or Fail. Beverly Hills: Sage.

Jobert, B. and P. Muller. 1987. Lốtat en action. Politiques publiques et corporatismes. Paris: Presses universitaires de France.

Kerr, D. H. 1976. "The Logic of đolicyôand Successful Policies." Policy Sciences 7 (3): 351363.

Kohler, R. 2002. "Labscapes: Naturalizing the Lab." History of Science 40 (4): 473-500.

Majone, G. 1989. Evidence, Argument, and Persuasion in the Policy Process. New Haven: Yale University Press.

Marsh, D., and A. McConnell. 2010. "Towards a Framework for Establishing Policy Success." Public Administration 88 (2): 564-583.

Mackenzie, D. and F. Muniesa, eds. 2007. Do Economists Make Markets? On the Performativity of Economics. Princeton: Princeton University Press.

McConnell, A. 2010. "Policy Success, Policy Failure and Grey Areas In-Between." Journal of Public Policy 30 (3): 345-362.

Molle, F. 2008. "Nirvana Concepts, Narratives and Policy Models: Insights from the Water Sector." Water Alternatives 1 (1): 131-156.

Molle, F. 2009. "Water, Politics, and River Basin Governance: Repoliticizing Approaches to River Basin Management." Water International 34 (1): 1-9.

Mollinga, P.P., and A. Bolding. 2004. "Research for Strategic Action" In The Politics of Irrigation Reform. Contested Policy Formulation and Implementation in Asia, Africa and Latin America, edited by P. P. Mollinga, 291-318. Aldershot: Ashgate.

Mosse, D. 2004. "Is Good Policy Unimplementable? Reflections on the Ethnography of Aid Policy and Practice." Development and Change 35 (4): 639-671.

Munro, J. 1993. "California Water Politics: Explaining Policy Change in a Cognitively Polarized Subsystem." In Policy Change and Learning: An Advocacy Coalition Approach, edited by P. A. Sabatier and H. C. Jenkins-Smith, 105-128. Boulder: Westview Press.

Palier, B. 2005. "Ambiguous Agreement. Cumulative Change: French Social Policy in the 1990s" In Beyond Continuity. Institutional Change in Advanced Political Economies, edited by W. Streeck and K. Thelen, 127-144. Oxford: Oxford University Press.

Radaelli, C. M. 1999. "Harmful Tax Competition in the EU: Policy Narratives and Advocacy Coalitions." Journal of Common Market Studies 37 (4): 661-682.

Radaelli, C. M. 2000. "Logiques de pouvoir et récits dans les politiques publiques de lỗnion européenne." Revue française de science politique 50 (2): 255-275.

Rap, E. 2006. "The Success of a Policy Model: Irrigation Management Transfer in Mexico." Journal of Development Studies 42 (8): 1301-1324.

Roe, E. 1994. Narrative Policy Analysis. Durham: Duke University Press.

Sabatier, P. A. and H. C. Jenkins-Smith, eds. 1993. Policy Change and Learning: An Advocacy Coalition Approach. Boulder: Westview Press.

Sécolier, P. 2009. Pratiques professionnelles, enjeux territoriaux et changement social. Lấvolution et la mutation des petits métiers de lấtang de Thau. Bruxelles: EME. 
Savey, S. et al. 1982. "La Pointe courte à Sète, naissance et mort dône classe socio-spatiale." In Cahiers de lôbservation du changement social, 7-176. Paris: CNRS.

Scharpf, F. 1999. Governing in Europe. Effective and Democratic?, Oxford: Oxford University Press.

Schmidt, V. A. and C. M. Radaelli. 2004. "Policy Change and Discourse in Europe: Conceptual and Methodological Issues." West European Politics 27 (2): 183-210.

Shore, C. and S. Wright, eds. 1997. Anthropology of Policy. Critical Perspectives on Governance and Power. London and New York: Routledge.

Stone, D. A. 1989. "Causal stories and the formation of policy agendas." Political Science Quarterly 104 (2): 281-299.

Trottier J. and P. Slack, eds. 2004. Managing Water Resources Past and Present. Oxford: Oxford University Press.

Van Assche, K. et al. 2012. ñPerforming Success and Failure in Governance: Dutch Planning Experiences. Ò Public Administration 90 (3): 567-581

Verlaque, C. 1987. Le Languedoc-Roussillon. Paris: Presses universitaires de France.

Verlaque, M. 2001. "Checklist of the Macroalgae of Thau Lagoon (Hérault, France), a Hot Spot of Marine Species Introduction in Europe." Oceanologica Acta 24 (1): 29-49.

Zittoun, P. 2013. La fabrique politique des politiques publiques. Paris: Presses de Sciences Po. 